Vishniac, H. S. \& Watson, S. W. (1953). J. gen. Microbiol. 8, 248-255.

\title{
The Steroid Requirements of Labyrinthula vitellina var. pacifica
}

\author{
BY HELEN S. VISHNIAC* AND S. W. WATSON \\ Haskins Laboratories, New York 17, N.Y., and the Woods Hole Oceanographic \\ Institution, Woods Hole, Massachusetts, U.S.A.†
}

SUMMARY : Labyrinthula vitellina var. pacifica requires a steroid as growth factor. Cholesterol, $\Delta^{4}$-cholestenone, fucosterol, and $\beta$-sitosterol are active. When cholesterol is modified by (1) the C $3+$ hydroxyl group becoming trans to the C10 methyl group, (2) esterification of the C3 hydroxyl group, or (3) saturation of the C5, 6 double bond, the resulting compound is inactive. Modification of the side chain of cholesterol or cholestenone by the addition of a C24, ethyl or vinyl group does not destroy activity but unsaturation at $\mathrm{C} 22,23$ does, as do the more marked changes found in diosgenin, deoxycorticosterone acetate, and methyltestosterone. Bile salts are inactive. The specificity of the requirement indicates that active steroids function as essential metabolites rather than solely as protective agents. Active steroids may be obtained by this micro-organism in nature from host plants or from diatoms and bacteria associated with the hosts.

The isolation in pure culture of the labyrinthula strains by Watson (to be published) made possible the investigation of their nutritional requirements. One isolate, L. vitellina var. pacifica, has been found to require a steroid for growth. Since such requirements are rare among micro-organisms, a detailed investigation of steroid specificity has been made.

\section{MATERIALS AND METHODS}

Stock cultures of isolates of $L$. macrocystis var. atlantica and $L$. minuta var. atlantica were maintained at $20^{\circ}$ in tubes containing the semi-solid medium given in Table 1 . The addition of $1.0 \mathrm{mg} \%(\mathrm{w} / \mathrm{v})$ of cholesterol rendered this medium suitable for the maintenance of $L$. vitellina var. pacifica.

The agar in this medium appears to be necessary as a physical support without which these organisms settle to the bottom of the tube, or cling to its sides, where they grow poorly. High viscosity methylcellulose $(0 \cdot 5 \%(\mathrm{w} / \mathrm{v})$, Hercules Powder Company) gave fair results as an alternative supporting agent but did not form a sufficiently homogeneous gel to give consistent or maximal growth. The constant motion provided by a rotating apparatus constructed after Baker (1949) substituted for mechanical support and allowed the smallest strain (L. minuta var. atlantica) to grow as well in a liquid as in an agar-containing medium. Tubes of liquid medium were placed in a rack held at an angle of $11.5^{\circ}$ to the horizontal and rotated at 21 r.p.m. by this apparatus. This method of cultivation appears most promising for more critical studies

* Present address: Department of Microbiology, Yale University, 310 Cedar St, New Haven 11, Conn.

$\dagger$ Contribution No. 623 from the Woods Hole Oceanographic Institution.

$\mp$ For the structure of steroids and the numbering system used see Deuel (1951). 
of non-steroid nutritional requirements of labyrinthula and is being further studied.

Since it was most convenient to use agar as supporting agent for the present investigations, only preliminary experiments on non-steroid nutritional requirements have been made. The agar used (Difco agar) contains significant amounts of various vitamins and inorganic compounds. The latter are also contributed

Table 1. Composition of stock medium. Quantities made up to $100 \mathrm{ml}$. with distilled water and $\mathrm{pH}$ value adjusted to $8 \cdot 0-8 \cdot 2$ with $\mathrm{KOH}$ after the medium had been boiled for $20 \mathrm{~min}$. and cooled to room temperature

\begin{tabular}{|c|c|c|c|}
\hline $\mathrm{NaCl}$ & $2 \cdot 5 \mathrm{~g}$. & Thiamine & $0.2 \mathrm{mg}$. \\
\hline $\mathrm{MgSO}_{4} \cdot 7 \mathrm{H}_{2} \mathrm{O}$ & $0.5 \mathrm{~g}$. & Nicotinic acid & $0 \cdot 1 \mathrm{mg}$. \\
\hline $\mathrm{K}_{2} \mathrm{HPO}_{4}$ & $0.01 \mathrm{~g}$. & Ca pantothenate & $0.1 \mathrm{mg}$ \\
\hline Ethylenediamine tetracetic acid* & $0.05 \mathrm{~g}$. & Pyridoxin. $\mathrm{HCl}$ & $0.04 \mathrm{mg}$. \\
\hline $\mathrm{CaCO}_{3}$ & $0.025 \mathrm{~g}$. & Pyridoxamin .2HCl & $0.02 \mathrm{mg}$. \\
\hline Mn (as manganous sulphate) & $2.0 \mathrm{mg}$ & $p$-Aminobenzoic acid & $0.01 \mathrm{mg}$. \\
\hline Zn (as sulphate) & $2 \cdot 0 \mathrm{mg}$ & Biotin & $0.5 \mu \mathrm{g}$. \\
\hline Fe (as ferrous sulphate) & $0.2 \mathrm{mg}$. & Cobalamin (vitamin $\mathbf{B}_{12}$ ) & $0.05 \mu \mathrm{g}$. \\
\hline Gelatin hydrolysate & $0 \cdot 1 \mathrm{~g}$. & Folic acid & $2 \cdot 5 \mu \mathrm{g}$ \\
\hline Agar & $0.2 \mathrm{~g}$. & & \\
\hline
\end{tabular}

* 'Versene'-free acid, Bersworth Chemical Co., Framingham, Mass.

to the medium by the gelatin hydrolysate. The gelatin hydrolysate used was made from Eastman gelatin hydrolysed with sulphuric acid and partially neutralized with barium hydroxide before filtration and final neutralization with KOH. The strains which we have maintained on the stock medium(Table 1) grow only slightly better and more consistently when the vitamins listed are added than when they are omitted. It seems probable that these strains do require one or more of the known vitamins. Our preliminary experiments indicated that the sodium, chloride, phosphate, magnesium, calcium, manganese, zinc and iron contents of the stock medium are approximately optimal.

Gelatin hydrolysate serves as carbon and nitrogen source. Glucose, sodium succinate hexahydrate, fumaric acid (neutralized with $\mathbf{K O H}$ ), glycerol, and sodium acetate trihydrate were ineffective as substrates in the presence of a non-toxic concentration of $\mathrm{NH}_{4} \mathrm{Cl}(0.02 \%, \mathrm{w} / \mathrm{v})$ added aseptically after autoclaving. The carbon sources tested were at the concentration of $0 \cdot 2 \%(\mathrm{w} / \mathrm{v})$. Monosodium glutamate $(0 \cdot 25 \%, \mathrm{w} / \mathrm{v})$ supported a slight amount of growth. The initial $\mathrm{pH}$ value of the medium could not be lowered without decreasing growth.

Under the conditions given stock cultures should be transferred once a week, although they will survive for a month if kept in the refrigerator after a 4- or 5 -day period of growth at $20^{\circ}$. The temperature tolerance of $L$. minuta var. atlantica extends from about $2^{\circ}$ (refrigerator) to $30^{\circ}$; cultures incubated at $37^{\circ}$ failed to grow at that temperature or when transferred to a room temperature of about $21-24^{\circ}$. L. vitellina var. pacifica and L. macrocystis var. atlantica grew rapidly at $20^{\circ}$ but were killed by incubation at $30-31^{\circ}$. 


\section{RESULTS}

L. vitellina var. pacifica was originally isolated on serum agar and did not grow in the absence of serum. The discovery that cream, but not yeast extract or a tryptic digest of casein, would substitute for serum suggested that a lipid growth factor was required. Non-toxic concentrations of bile salts $(1.0,5 \cdot 0 \mathrm{mg} . / 100 \mathrm{ml}$.), lecithin $(1.0,5 \cdot 0,10 \cdot 0 \mathrm{mg} . / 100 \mathrm{ml}$.), Tween 40 ( $1.0 \mathrm{mg} . / 100 \mathrm{ml}$; ; polyoxyethylene sorbitan palmitate, Atlas Powder Co.), Tween 80 (1.0 mg./100 ml.; polyoxyethylene sorbitan oleate, Atlas Powder Co.), or glycerol mono-oleate $(1.0 \mathrm{mg} . / 100 \mathrm{ml}$.) failed to support continued growth. Cholesterol $(1.0 \mathrm{mg} . / 100 \mathrm{ml}$.) was effective in preliminary experiments.

The stock medium (without cholesterol) was used in studying the specificity of this steroid requirement. Ten ml. lots of medium were distributed in $25 \mathrm{ml}$. glass-capped Erlenmeyer flasks which were in turn sealed with transparent cellulose tape between two Pyrex glass kitchen trays. Steroids were added as freshly made solutions in commercial absolute ethanol, before autoclaving. Ergosterol was also used as an unsterilized ethanolic solution added after autoclaving. No contaminations occurred in this experiment. The amount of ethanol added is critical; $0 \cdot 1 \mathrm{ml}$. ethanol $/ 10 \mathrm{ml}$. medium added after autoclaving completely suppressed growth in the presence of cholesterol. Ethanol is not completely removed by autoclaving; $0.25 \mathrm{ml}$. ethanol/10 ml. medium added before autoclaving inhibited growth although half this amount did not. No more than $0.05 \mathrm{ml}$. ethanol $/ 10 \mathrm{ml}$. medium was added after autoclaving, nor more than $0.125 \mathrm{ml}$. $/ 10 \mathrm{ml}$. before autoclaving, in these experiments. The addition of the steroids as ethanolic solutions gave fairly uniform dispersion. No better results were obtained by using bile salts to solubilize cholesterol. The inoculum consisted of one or two drops of a $1 / 10$ dilution of a stock culture in basal medium. Inoculated flasks were incubated in an incubator controlled at $18-20^{\circ}$.

The steroid preparations used were: cholesterol (U.S.P.); cholesteryl acetate (recrystallized from a preparation of Dr N. A. Milas); cholesteryl laurate (m.p. 74-75 ${ }^{\circ}$, gift of Dr M. Calvin, Radiation Laboratory, University of California); cholesteryl palmitate, epicholesterol, progesterone, estrone, and deoxycorticosterone acetate (gifts of Dr H. Sobotka, Mt. Sinai Hospital); coprosterol (m.p. 92-99 ${ }^{\circ}$ ), $\beta$-cholestanol (m.p. 145 ${ }^{\circ}$ ), $\Delta^{4}$-cholestenone (m.p. $79-80^{\circ}$ ), and cholestanone (m.p. 129-130 ${ }^{\circ}$ ) (gifts of Dr Ivan Salamon, Sloan Kettering Institute for Cancer Research); ergosterol (The Matheson Co., Inc., East Rutherford, N.J., recrystallized before use); ergosterol, zymosterol (m.p. 108-115,$[\alpha]_{D}+34\left[\mathrm{CHCl}_{3}\right]$ ), and 5-dihydroergosterol (gifts of Dr O. N. Breivik, the Fleischmann Laboratories); fucosterol, brassicasterol, and $\beta$-sitosterol (gifts of Dr W. Bergman, Sterling Chemistry Laboratories, Yale University); $\beta$-sitosterol (L. Light and Co., Ltd., Colnbrook, Bucks, England); mixed soya sitosterols ( $\beta$ and $\gamma$ ) and stigmasterol (The Glidden Co., Chicago, Ill.); calciferol (Nutritional Biochemicals Corp., Cleveland, Ohio); methyltestosterone and ethinyl estradiol (Schering Corp., Bloomfield, N.J.); cortisone (gift of Dr T. H. Jukes, Lederle Laboratories); diosgenin (gift of Dr Monroe 
E. Wall, Eastern Regional Research Laboratory, United States Department of Agriculture); and progesterone (gift of Dr K. Schindler).

Table 2. Steroids as growth factors for Labyrinthula vitellina var. pacifica

\begin{tabular}{|c|c|c|}
\hline & $\begin{array}{l}\text { Steroid added } \\
\text { to } 10 \mathrm{ml} . \\
\text { basal medium }\end{array}$ & Optical density \\
\hline None; no inoculum & $\mathbf{0}$ & 0.07 \\
\hline $\left.\begin{array}{c}\text { Cholesterol } \\
\text { No inoculum }\end{array}\right\}$ & $0.05 \mathrm{mg}$. & 0.07 \\
\hline None; inoculated & 0 & $0 \cdot 07,0.08$ \\
\hline Cholesterol & $\begin{array}{l}0.005 \mathrm{mg} . \\
0.01 \mathrm{mg} . \\
0.025 \mathrm{mg} . \\
0.05 \mathrm{mg} . \\
0.1 \mathrm{mg} . \\
0.25 \mathrm{mg} . \\
0.5 \mathrm{mg} .\end{array}$ & $\begin{array}{l}0 \cdot 09^{*} \\
0 \cdot 17-18 \\
0 \cdot 31 \\
0 \cdot 31,0 \cdot 36,0 \cdot 41 \\
0 \cdot 37 \\
0 \cdot 41 \\
0 \cdot 50\end{array}$ \\
\hline$\Delta^{4}$-Cholestenone & $\begin{array}{l}0.0025 \mathrm{mg} . \\
0.005 \mathrm{mg} \text {. } \\
0.01 \mathrm{mg} \text {. } \\
0.025 \mathrm{mg} \text {. } \\
0.05 \mathrm{mg} \text {. } \\
0.1 \mathrm{mg} \text {. } \\
0.25 \mathrm{mg} .\end{array}$ & $\begin{array}{l}0 \cdot 09 * \\
0 \cdot 19,0 \cdot 12 \dagger \\
0 \cdot 30 \\
0 \cdot 33 \\
0 \cdot 37 \\
0 \cdot 37,0 \cdot 41 \\
0 \cdot 33\end{array}$ \\
\hline Fucosterol & $\begin{array}{l}0.005 \mathrm{mg} \text {. } \\
0.01 \mathrm{mg} \text {. } \\
0.025 \mathrm{mg} \text {. } \\
0.05 \mathrm{mg} \text {. }\end{array}$ & $\begin{array}{l}0 \cdot 12-13 \dagger \\
0 \cdot 25 \\
0 \cdot 31 \\
0 \cdot 33\end{array}$ \\
\hline$\beta$-Sitosterol & $\begin{array}{l}\text { 0.005 mg. } \\
0.01 \mathrm{mg} . \\
0.025 \mathrm{mg} \text {. } \\
0.05 \mathrm{mg} \text {. } \\
0.1 \mathrm{mg} . \\
0.25 \mathrm{mg} .\end{array}$ & $\begin{array}{l}0 \cdot 08 * \\
0 \cdot 16 \\
0 \cdot 30 \\
0 \cdot 34-36,0 \cdot 29 \\
0 \cdot 32-33 \\
0 \cdot 38-40\end{array}$ \\
\hline
\end{tabular}

* Indicates absence of growth, $\dagger$ slight growth (150 organisms or more in a low power microscope field) where the optical density data do not clearly provide this information.

The positive results are given in Table 2 in terms of the optical density of the cultures reached after 8 days of incubation. Cholesterol, $\Delta^{\mathbf{4}}$-cholestenone, fucosterol and $\beta$-sitosterol were active as growth factors. The following compounds showed slight activity at the concentrations given parenthetically: epicholesterol $(0.1 \mathrm{mg} . / 10 \mathrm{ml}$.), so yasitosterols $(0.025 \mathrm{mg} . / 10 \mathrm{ml}$; ) higher concentrations toxic), ergosterol (added after autoclaving, $0 \cdot 01-0 \cdot 1 \mathrm{mg} . / 10 \mathrm{ml}$. but not consistently), brassicasterol $(0 \cdot 01-0 \cdot 1 \mathrm{mg} . / 10 \mathrm{ml}$.), and stigmasterol $(0.1 \mathrm{mg} . / 10 \mathrm{ml}$.). We consider these compounds to be really inactive because of the low level of growth (optical densities usually less than $0 \cdot 19$ ) and the relatively high concentrations required for even this little growth. The purity of these steroid preparations was not high and steroids deteriorate more or less rapidly in any case; contaminants or degradation products were probably responsible for the slight apparent activity. When the occurrence of growth was doubtful a microscopic examination of the culture was always made. The 
other compounds tested were inactive, although not completely inhibitory over at least a portion of the experimental range of concentrations. They were as follows: cholesteryl acetate (toxic at $\mathbf{0 . 1} \mathrm{mg} . / 10 \mathrm{ml}$.), cholesteryl laurate and cholesteryl palmitate (toxic at $0.025 \mathrm{mg} . / 10 \mathrm{ml}$.), 3 - $\beta$-cholestanol (inhibitory at $0.1 \mathrm{mg} . / 10 \mathrm{ml}$ ), coprosterol (toxic at $0.05 \mathrm{mg} . / 10 \mathrm{ml}$.), cholestanone (inhibitory at $0.1 \mathrm{mg} . / 10 \mathrm{ml}$.), 5-dihydroergosterol, zymosterol (toxic at $0.05 \mathrm{mg} . / 10 \mathrm{ml}$.), calciferol (toxic at $0.025 \mathrm{mg} .10 \mathrm{ml}$.), cortisone, deoxycorticosterone acetate (toxic at $0.05 \mathrm{mg} . / 10 \mathrm{ml}$.), estrone (toxic at $0.01 \mathrm{mg} . / 10 \mathrm{ml}$.), ethinyl estradiol (toxic at $\mathbf{0 . 0 1} \mathrm{mg}$. $/ 10 \mathrm{ml}$.), methyltestosterone (inhibitory at $0.025 \mathrm{mg} . / 10 \mathrm{ml}$.) and diosgenin. Progesterone was so toxic that no growth occurred at the lowest concentration tested $-0.005 \mathrm{mg} . / 10 \mathrm{ml}$. of medium. A compound was judged to be toxic when it completely inhibited growth in the presence of $\mathbf{0 . 0 5} \mathbf{m g}$. cholesterol $/ \mathbf{1 0} \mathrm{ml}$. medium. The significance of the apparent inactivity of the more toxic compounds is doubtful for the same reasons that cause us to doubt the significance of slight activities.

Comparison of the structures of active and inactive compounds leads to the following conclusions:

(1) The oxidation of the hydroxyl group of C3 to a keto group, and the simultaneous shift of the double bond from 5:6 to $4: 5$ does not affect activity since cholestenone was active.

(2) The configuration of the hydroxyl group at C3 must be cis to the $\mathrm{C} 10$ methyl group; epicholesterol was inactive.

(3) Esterification of the hydroxyl group destroys activity; none of the cholesteryl esters was active.

(4) Saturation of the 5:6 double bond destroys activity; neither coprosterol nor its C5 stereoisomer, cholestanol, were active. Saturation of the 4:5 double bond of cholestenone likewise destroys activity; cholestanone was inactive.

(5) The side chain of cholesterol may be modified by the addition of an ethyl group at $\mathrm{C} 24$, but only one of the two possible $\mathrm{C} 24$ stereoisomers resulting is active; the activity of mixed $\beta$ - and $\gamma$-sitosterols occurred at a level indicating activity of $\beta$-sitosterol alone.

(6) A vinyl group at $\mathrm{C} 24$ is also permissible; fucosterol was active.

(7) Unsaturation of the side chain at C22, 23 destroys activity; stigmasterol was inactive although $\beta$-sitosterol (22-dihydrostigmasterol) was active.

(8) Changing the side chain of cholesterol to that of a saponin destroys activity; diosgenin was inactive.

(9) Shortening the side chain of cholestenone to that of deoxycorticosterone acetate or methyltestosterone destroys activity. The other compounds tested differed in more than one respect from active compounds.

\section{DISCUSSION}

The physiologic importance of steroids in higher animals is well recognized. However, while steroids are found in many groups of micro-organisms (Deuel, 1951), they do not occur in all micro-organisms. Sifferd \& Anderson (1936) isolated significant amounts of a steroid mixture from Azotobacter chroococcum which had been grown on a steroid-free medium; Guirard, Snell \& Williams 
(1946) isolated a steroid fraction from several Lactobacillus spp. Yet Anderson, Schoenheimer, Crowder \& Stodola (1935), applying even more searching techniques to Mycobacterium tuberculosis, were able to confirm the many earlier reports which stated that no steroids could be found in these bacteria. Corynebacterium diphtheriae (Chargaff, 1933b), the BCG strain of Mycobacterium tuberculosis (Chargaff, 1933a), and Bacterium coli (Behring, 1930) also appear to lack steroids. Heilbron (1942), reviewing the work of his laboratory on the steroid composition of algae, reported that the blue-green algae contained no steroids. It is therefore difficult to postulate a general essential role of steroids in micro-organisms.

Evidence that steroids may nevertheless be essential metabolites for a few micro-organisms has been provided by nutritional experiments. The degree to which such requirements represent a special metabolic evolution will become clearer when more such organisms are known, and when we have some idea of the biochemical role of these compounds. Unfortunately, the demonstration that cholesterol is a necessary ingredient in a medium does not prove that it has a metabolic role within the micro-organism. The toxicity of unsaturated fatty acids was first noted by Hutner (1942) to be annulled by cholesterol, among other compounds. This subject has been discussed in detail recently by Pollock (1949) and by Kodicek (1949). Ordinary bacteriological broths may require the addition of cholesterol solely as a protective agent for sensitive organisms (see Lwoff 1947, on the subject of peptone media for Moraxella and Neisseria). A medium initially fatty acid-free can be made toxic by unsaturated fatty acids produced by a micro-organism before visible growth has occurred (as Haemophilus pertussis, see Pollock, 1949). Organisms which require oleic acid as a growth factor may therefore require cholesterol, or other substances with a similar 'buffer' action, to maintain a low but constant supply of oleic acid. It follows that pure cultures, media of known composition, and knowledge of the specificity of the requirement, are necessary if one is to conclude for a given micro-organism that a steroid is an essential metabolite rather than solely a protective agent.

None of these desiderata has yet been attained in the nutritional studies which indicate cholesterol requirements in amoebae (see Lwoff, 1951). It is difficult to evaluate Devloo's (1938) claim that yeast ' $W$ ' required 'biosterol' in the light of present-day steroid chemistry. The specificity studies of Cailleau (1937) on the steroid requirement of a pure culture of Trichomonas columbae, however, indicate a true metabolic requirement which may be general in this group of protozoa. Eutrichomastix colubrorum (Cailleau, 1938b) in pure culture, and Trichomonas batrachorum (Cailleau, 1939) and T. foetus (Cailleau, 1938a) in mixed cultures also required cholesterol. Unpublished data of Hutner and Sanders have confirmed the cholesterol requirement of $T$. foetus in pure culture. The only other steroid-requiring micro-organisms which have been reported are the pleuropneumonia-like organisms studied by Edward \& Fitzgerald (1951), which required cholesterol; of the related compounds tested stigmasterol and cholestanol were active.

The metabolic role of cholesterol in these organisms, and in labyrinthula, 
is unknown. The specificity of the requirement rules out the possibilities suggested by the activity of cortisone (Gaines, Broquist \& Williams, 1951) and dehydroepiandrosterone (Gaines \& Totter, 1950) in replacing leucovorin and pteroylglutamic acid for Leuconostoc citrovorum and Streptococcus faecalis. Furthermore, folic acid was present in our basal medium for labyrinthula. It is also interesting to note that the specificity of the steroid requirement of L. vitellina var. pacifica differs from that of Trichomonas columbae. T. columbae utilized 5:6 saturated sterols, cholesteryl esters and ergosterol as growth factors; labyrinthula did not. Conversion of the C3 hydroxyl group to a keto group destroyed activity for Trichomonas columbae but not for labyrinthula. The pleuropneumonia-like organisms of Edward \& Fitzgerald utilized cholestanol and stigmasterol, but not cholesteryl esters, ergosterol, or coprosterol, thus exhibiting still another pattern of specificity.

Where does $L$. vitellina var. pacifica obtain steroids in nature? This variety was found associated with Zostera marina, Ulva spp., and material from phytoplankton and zooplankton tows. The common steroids of higher plants (as Zostera marina) are the sitosterols and stigmasterol; of these $\beta$-sitosterol is active. 'Sitosterol' is also commonly present in the green algae (Heilbron, 1942), including Ulva lactuca. Diatoms and bacteria are conspicuous associates of the host plants. The diatom Nitzschia closterium contains fucosterol (Heilbron, 1942) which is active. Evidence that bacteria may provide utilizable steroids (though labyrinthula is not phagotrophic) was presented by isolation plates of non-nutrient sea-water agar on which $L$. vitellina var. pacifica grew in and around bacterial colonies but not when more distant from bacteria.

We are very grateful to those (indicated in the text) whose generosity in donating steroids made this study possible. We also wish to thank Michael Bach for assistance and Dr S. H. Hutner and Dr W. Vishniac for discussion of this work. The Haskins Laboratories investigations of microbial nutrition are assisted by grants from the Lederle Laboratories Division of the American Cyanamid Co. and the Rockefeller Foundation.

\section{REFERENCES}

Anderson, R. J., Schoenheimer, R., Crowder, J. A. \& Stodola, F. H. (1935). Die Chemie der Tuberkelbazillen-Lipoide. XL. Über das Vorkommen von Sterinen in Tuberkelbazillen. Hoppe-Seyl. Z. 237, 40.

BAKER, P. B. (1949). A rotating test-tube apparatus for experimental fermentations. Nature, Lond. 163, 732.

Behring, H. v. (1930). Enthalten Bakterien Sterine? Hoppe-Seyl. Z. 192, 112.

Cailleau, R. (1937). La nutrition des flagellés tétramitidés. Les sterols, facteurs de croissance pour les trichomonades. Ann. Inst. Pasteur, $59,7$.

Cailleau, R. (1938a). Le cholestérol et l'acide ascorbique, facteurs de croissance pour le flagellé tétramitidé Trichomonas foetus Riedmuller. C.R. Soc. Biol., Paris, 127, 861.

Cailleau, R. (1938b). L'acide ascorbique et le cholestérol, facteurs de croissance pour le flagellé Eutrichomastix colubrorum. C.R. Soc. Biol., Paris, 127, 1421.

Cailleau, R. (1939). Le cholestérol, facteur de croissance pour le flagellé Trichomonas batrachorum. C.R. Soc. Biol., Paris, 130, 1089.

Chargaff, E. (1933a). UUber die Lipoide des Bacillus Calmette-Guerin (BCG). HoppeSeyl. Z. 217, 115. 
Chargaff, E. (1933b). Über das Fett und das Phosphatid der Diphtheriebakterien. Hoppe-Seyl. Z. 218, 233.

Deuel, Jr. H. J., (1951). The Lipids. I. Chemistry. New York: Interscience Pub., Inc.

Devloo, R. (1938). Un stérol indispensable à la levure W. Arch. int. Physiol. 46, 157.

Edward, D. G. FF. \& Fitzgerald, W. A. (1951). Cholesterol in the growth of organisms of the pleuropneumonia group. J. gen. Microbiol. 5, 576.

Gaines, D. S., Broquist, H. P. \& Williams, W. L. (1951). Certain relationships between pteroylglutamic acid, citrovorum factor, and cortisone. Proc. Soc. exp. Biol., N.Y. 77, 247.

Gaines, D. S. \& Totter, J. R. (1950). Pteroylglutamic acid-like effect of dehydroisoandrosterone on growth of certain micro-organisms. Proc. Soc. exp. Biol., N.Y. 74, 558 .

Guirard, B. M., Snell, E. E. \& Williams, R. J. (1946). The nutritional role of acetate for lactic acid bacteria. I. The response to substances related to acetate. Arch. Biochem. 9, 361.

Heilbron, I. M. (1942). Some aspects of algal chemistry. J. chem. Soc. p. 79.

Hutner, S. H. (1942). Some growth requirements of Erysipelothrix and Listerella. J. Bact. 43, 629.

Kodicek, E. (1949). The effect of unsaturated fatty acids on Gram-positive bacteria. Symp. Soc. Exp. Biol. 3, Selective Toxicity and Antibiotics, p. 217.

Lwoff, A. (1947). Sur le role du serum dans le développement de Moraxella lacunata et de Neisseria gonorrhae. Ann. Inst. Pasteur, 73, 735.

LwoFf, M. (1951). Nutrition of parasitic amebae. In Biochemistry and Physiology of Protozoa, 1, 235. New York: Academic Press, Inc.

Pollock, M. R. (1949). The effects of long-chain fatty acids on the growth of Haemophilus pertussis and other organisms. Symp. Soc. exp. Biol. 3, Selective Toxicity and Antibiotics, p. 193.

Sifferd, R. H. \& ANDerson, R. J. (1936). Über das Vorkommen von Sterinen in Bakterien. Hoppe-Seyl. Z. 239, 270.

(Received 18 August 1952) 